\title{
O Sol, o motor das variabilidades climáticas
}

\section{The Sun, the engine of climate variability}

\author{
Antônio Carlos Zuffo
}

DOI: $10.4322 /$ dae.2014.142

Muito se tem falado a respeito da seca que estamos atravessando há alguns meses, o que pode nos levar ao desabastecimento de energia elétrica e água, dois recursos essenciais às atividades de nossa sociedade moderna. Alguns estudos dizem que seca igual somente daqui a 3.378 anos. Outros atribuem a seca às atividades humanas, principalmente ao bloqueio realizado pela poluição de São Paulo, nossa maior região industrializada, que impediria a ocorrência dos "rios voadores". Já ouvi até mesmo culparem a Parada Gay, realizada em São Paulo, por São Pedro castigar nosso estado com a falta de chuvas. Mas, afinal, quais seriam os motivos para essa estiagem?

Primeiramente, gostaria de explicar que o homem não tem poder para alterar o clima do nosso planeta; não somos tão poderosos assim. Podemos, sim, alterar o microclima urbano, com o aumento da temperatura e, consequentemente, do efeito convectivo em nossas cidades ou da umidade no entorno de uma grande barragem, mas para por aí. O macroclima global é definido tanto pela circulação atmosférica quanto pela oceânica, que têm a capacidade de redistribuir o calor recebido do Sol, nossa estrela maior.

A Terra recebe em média, na alta atmosfera, cerca de 1.400 watts por metro quadrado por segundo $\left(\mathrm{W} / \mathrm{m}^{2} / \mathrm{s}\right)$ do Sol. Essa quantidade de energia é equivalente ao poder energético de $9.10^{20}$ litros de gasolina consumidos por minuto, a dez milhões de vezes a produção mundial de petróleo ou, ainda, a dez bilhões de vezes a potência da Usina Hidrelétrica de Itaipu. Dessa forma, uma variação de apenas $0,01 \%$ na atividade solar impactaria muito a quantidade de energia que atinge nosso planeta. A pergunta que se faz é: qual seria o impacto no clima terrestre se o Sol diminuísse a emissão de energia ou a aumentasse? Qual seria o efeito de aumentar ou diminuir a temperatura de um forno

\section{Antônio Carlos Zuffo}

Graduado em Engenharia Civil pela Universidade Estadual de Campinas (1985). Mestre em Engenharia Civil (1993) e doutor em Engenharia Hidráulica e Saneamento pela Universidade de São Paulo (1998). Pós-doutor em Engenharia Ambiental pela Universidade de Toronto, Ontário, Canadá. Professor associado da Universidade Estadual de Campinas.

\section{Endereço para correspondência:}

Universidade Estadual de Campinas, Faculdade de Engenharia Civil, Arquitetura e Urbanismo, Departamento de Recursos Hídricos

Avenida Alberto Einstein, 951 - Barão Geraldo - Campinas - São Paulo - SP

CEP: 13083-852 - Caixa postal: 6021

E-mail: zuffoafec.unicamp.br 
no cozimento dos alimentos? Há alguma alteração? Se sim, por que não haveria no planeta Terra?

O Sol é muito maior que a Terra e podemos assumir que seja suficientemente maior que ela a ponto de seus raios atingirem nosso planeta paralelamente, considerando apenas sua face iluminada, ou melhor, um disco recebendo a luz, se considerarmos sua área projetada. Nesse contexto, o planeta receberia a mesma quantidade de energia por toda a sua superfície projetada, porém ele não é um círculo ou um disco, mas, sim, uma esfera, conforme ilustrado pela Figura 1.

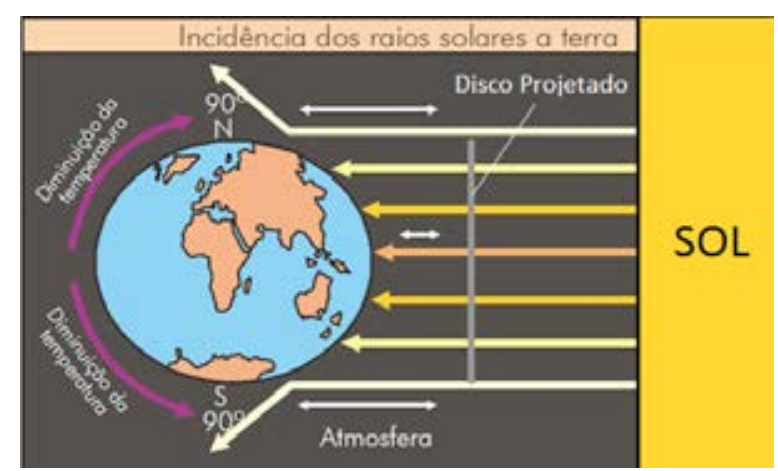

Figura 1 - Incidência dos raios solares na Terra. Fonte: http://geografalando.blogspot.com.br/2012/12/ clima-influencia-da-latitude_1486.html

Devido à esfericidade da Terra, os raios solares que atingem a região do Equador (latitude zero) são perpendiculares à superfície e os que atingem as regiões de latitudes maiores são inclinados. Apesar de o metro quadrado da área projetada receber a mesma quantidade de energia, as áreas reais são diferentes, pois não são mais projeções. Dessa forma, quanto maior for a latitude, maior será a área que receberá a mesma quantidade de energia e menor será a temperatura.

A diferença de temperatura, então, é criada sobre a superfície. A terra aquece mais rapidamente que a água e, dessa forma, as maiores extensões de terra próximas ao Equador se aquecerão mais rapidamente. Nessas regiões, após o aquecimento da terra, o ar também se aquece e se expande, diminuindo sua densidade. Assim, há o fenômeno de convecção térmica, em que o ar quente e úmido se eleva, perde gradativamente sua capacidade de reter umidade e são formadas as nuvens e, posteriormente, as precipitações. Então, na linha do Equador, encontram-se as regiões quentes e úmidas, nas quais existem as florestas tropicais.

Como a Terra é inclinada em relação ao seu eixo, a faixa mais quente move-se sazonalmente, conforme ilustrado pela Figura 2. Esse fenômeno é responsável pela formação das estações do ano ou pelo efeito sazonal.

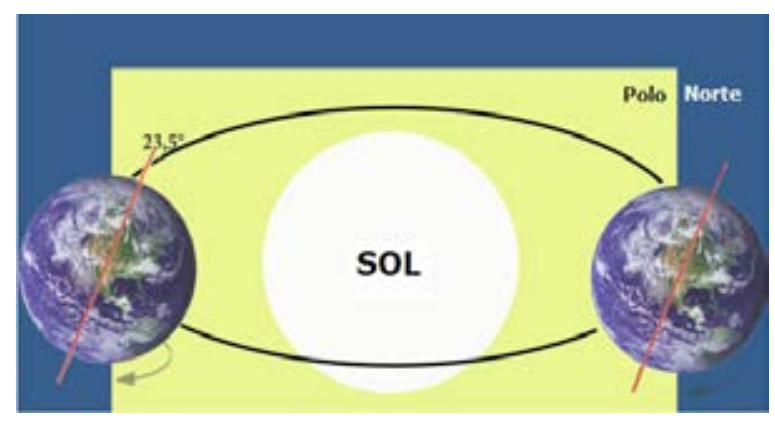

Figura 2 - Inclinação da Terra em relação ao plano de translação ao redor do Sol.

Uma vez que a Terra é envolvida por uma atmosfera, esta é responsável pela movimentação das massas de ar. A convecção térmica provoca uma diminuição da pressão atmosférica e essa baixa pressão leva à movimentação das massas de ar adjacentes mais frias e mais densas para ocupar a região em que houve a ascensão de ar quente. Assim, na faixa do Equador, há um predomínio de zonas de baixa pressão, que são, por conseguinte, regiões de grandes precipitações.

A massa de ar que ascende no Equador deve descer novamente para a superfície, de modo que a massa de ar quente e úmida, na medida em que sobe, perde calor e umidade. No alto, no limite da tropopausa, essa massa de ar passa a se mover em direção aos polos (Norte e Sul). Como a Terra 
possui rotação em torno de seu eixo, a velocidade tangencial no Equador é maior que nas latitudes mais altas. Essa diferença inercial provoca um adiantamento da massa em relação à sua posição inicial de subida na alta atmosfera, à medida que se afasta do Equador, criando ventos de oeste na alta atmosfera. Nesse deslocamento, mais ou menos nas latitudes $30^{\circ}$, há a descida da massa de ar e, nesse movimento descensional, provoca um arraste de ar em direção contrária das altas para as baixas latitudes, conforme ilustrado pela Figura 3. Da latitude $30^{\circ}$ Norte ou Sul, região de alta pres-

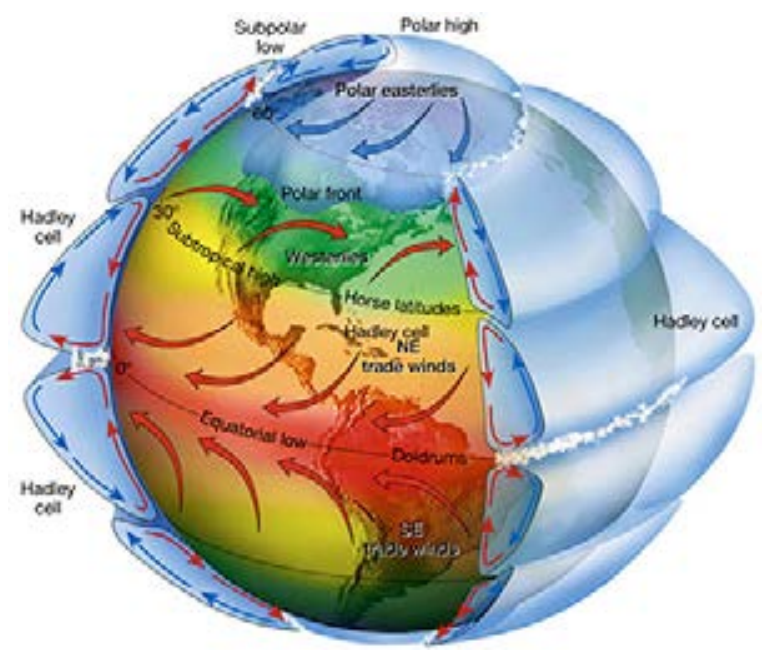

Figura 3 - Modelo teórico de circulação atmosférica, sem considerar a distribuição dos continentes.

Fonte: The Atmosphere, 8th edition, Lutgens and Tarbuck, 8th edition, 2001.

são, a massa de ar já seca desce da alta atmosfera, provoca o secamento dessas regiões, definindose assim as faixas dos desertos na Terra (Latitudes $30^{\circ} \mathrm{NeS}$ ).

A partir dessas regiões de alta pressão, as massas de ar deslocam-se para o norte e o sul. As massas que sobem para o norte, falando das zonas de alta pressão do Hemisfério Sul, também pelo efeito inercial, saem de um raio menor, com velocidade tangencial menor, para uma latitude menor, com maior raio e maior velocidade tangencial; dessa forma, essas massas de ar têm velocidades meno-

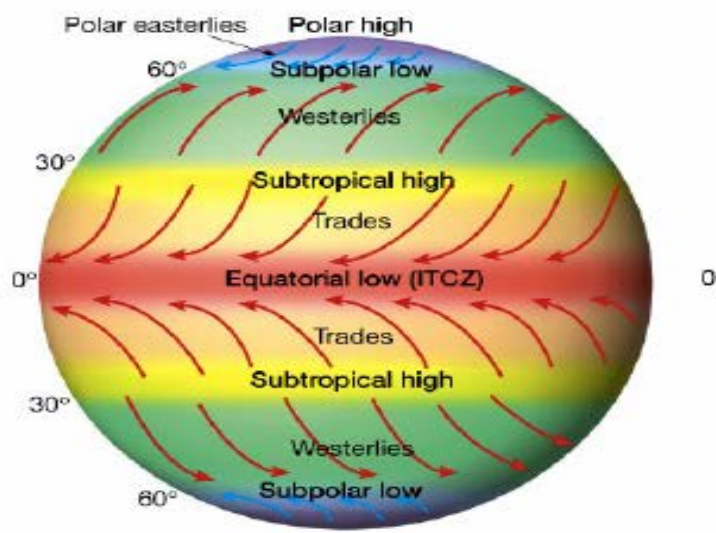

(a)

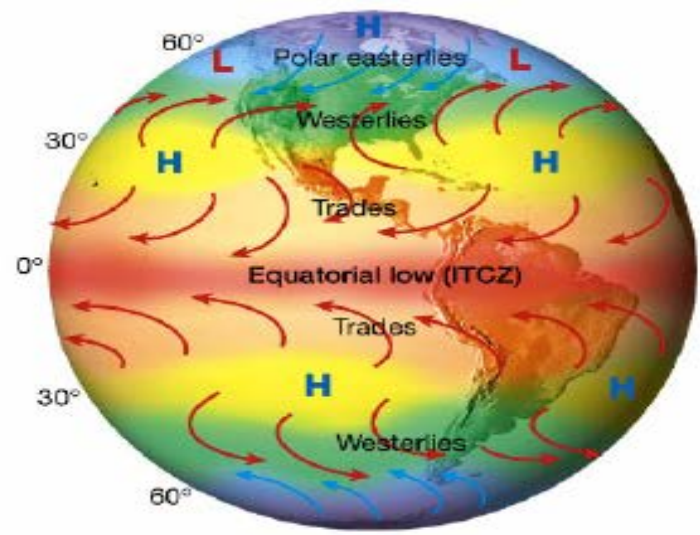

(b)

Figura 4 - Modelo teórico da circulação atmosférica para a baixa atmosfera (a) e da circulação na baixa atmosfera considerando a distribuição continental real (b)

Fonte: The Atmosphere, 8th edition, Lutgens and Tarbuck, 8th edition, 2001.

res e se atrasam em relação à velocidade da região, gerando correntes de ar de leste para oeste, que definem os ventos alísios, conforme ilustrado nas Figuras 3 e 4.

A Figura 3 ilustra o modelo teórico da circulação atmosférica, mas não leva em consideração a distribuição heterogênica dos continentes no globo, tampouco a existência de grandes cadeias montanhosas, que formam barreiras naturais para a livre circulação das massas de ar, como as montanhas do Himalaia, na Ásia, e a cordilheira dos Andes, na América do Sul. Na Figura 4, é apresentada a circulação dos ventos na baixa atmosfera para o modelo teórico (a) e a situação real (b), esta consi- 
derando as influências das cadeias montanhosas e a distribuição heterogênica dos continentes.

No Hemisfério Norte, há mais terra do que no Hemisfério Sul, de modo que suas temperaturas sofrem maiores variações, tanto para as máximas quanto para as mínimas. Os grandes corpos d'água são excelentes reguladores de temperatura; dessa forma, no Hemisfério Sul, por conter maior quantidade de água, o clima é mais regulado por ela, sendo menos afetado pelas grandes variações de temperatura se comparado com o Hemisfério Norte.

As Figuras 5 e 6, por sua vez, ilustram as variações de pressão atmosférica nos dois hemisférios para dois meses do ano: janeiro (Figura 5) e julho (Figura 6). $\mathrm{Na}$ Figura 5, a linha azul mostra uma maior concentração de área de terra, que produz maior aquecimento no verão do Hemisfério Sul; portanto, nessa região ocorrem as convecções térmicas e baixas pressões. $\mathrm{Na}$ linha de $30^{\circ}$ Norte, observam-se as regiões de alta pressão atmosférica, que definem as áreas predominantemente secas e representadas em amarelo. No mês de julho, a extensão de área de terra que recebe incidência direta da luz solar é muito maior para o Hemisfério Norte e as áreas de baixa pressão são muito mais pronunciadas na Ásia, provocando as famosas chuvas de monções no norte da Índia e Bangladesh. O sul da América do Sul fica encravado entre duas zonas de alta pressão atmosférica, localizadas nos oceanos Atlântico e Pacífico. Na Figura 6, as zonas de alta pressão atmosférica (linha contínua de $30^{\circ}$ Sul de latitude) ocorrem predominantemente nos oceanos, mas também atingem o sul da América do Sul, África e Oceania (mais na Austrália), que possuem inversos secos.

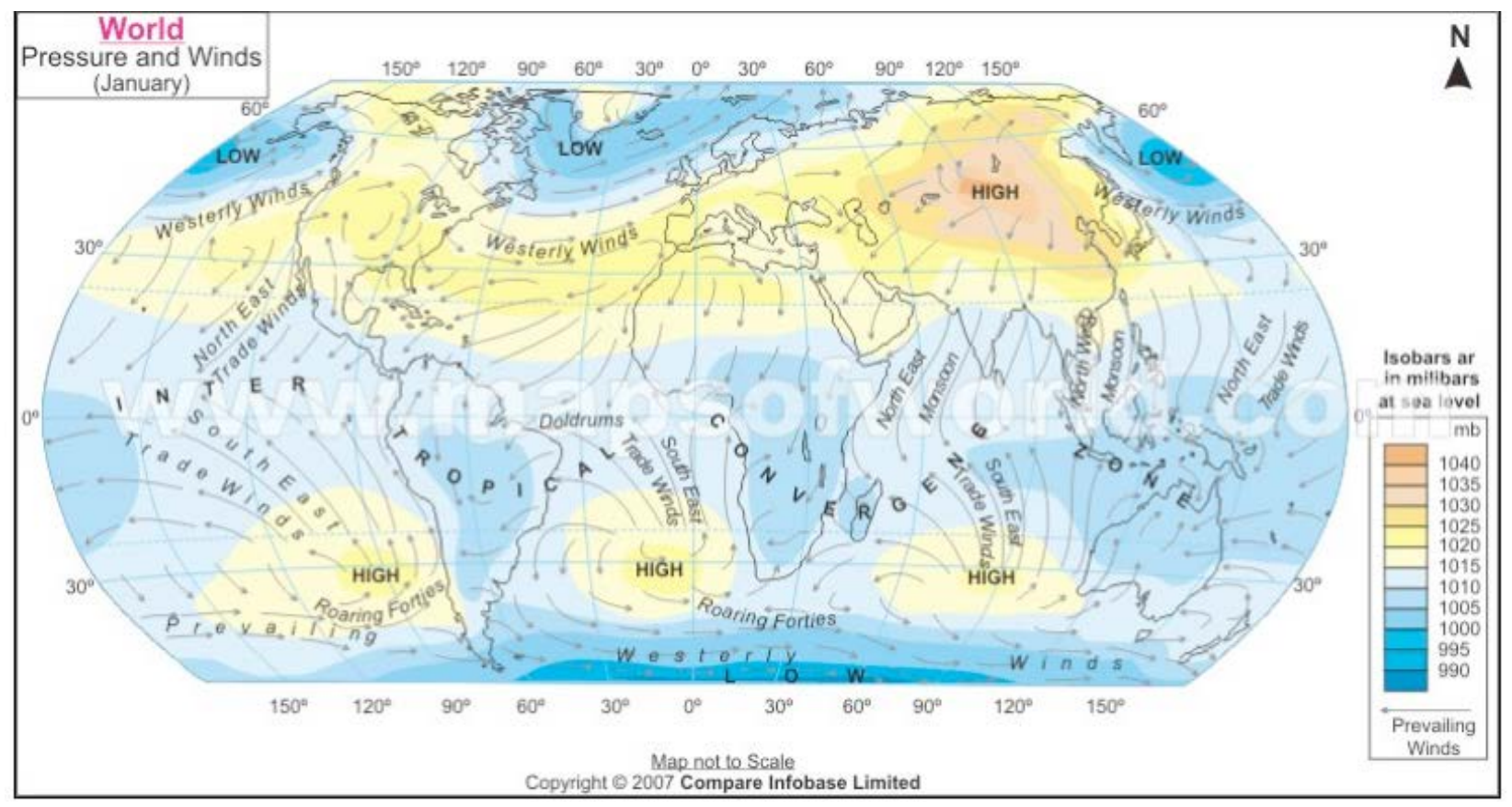

Figura 5 - Média das pressões atmosféricas para o mês de janeiro.

Fonte: Maps of the world. 


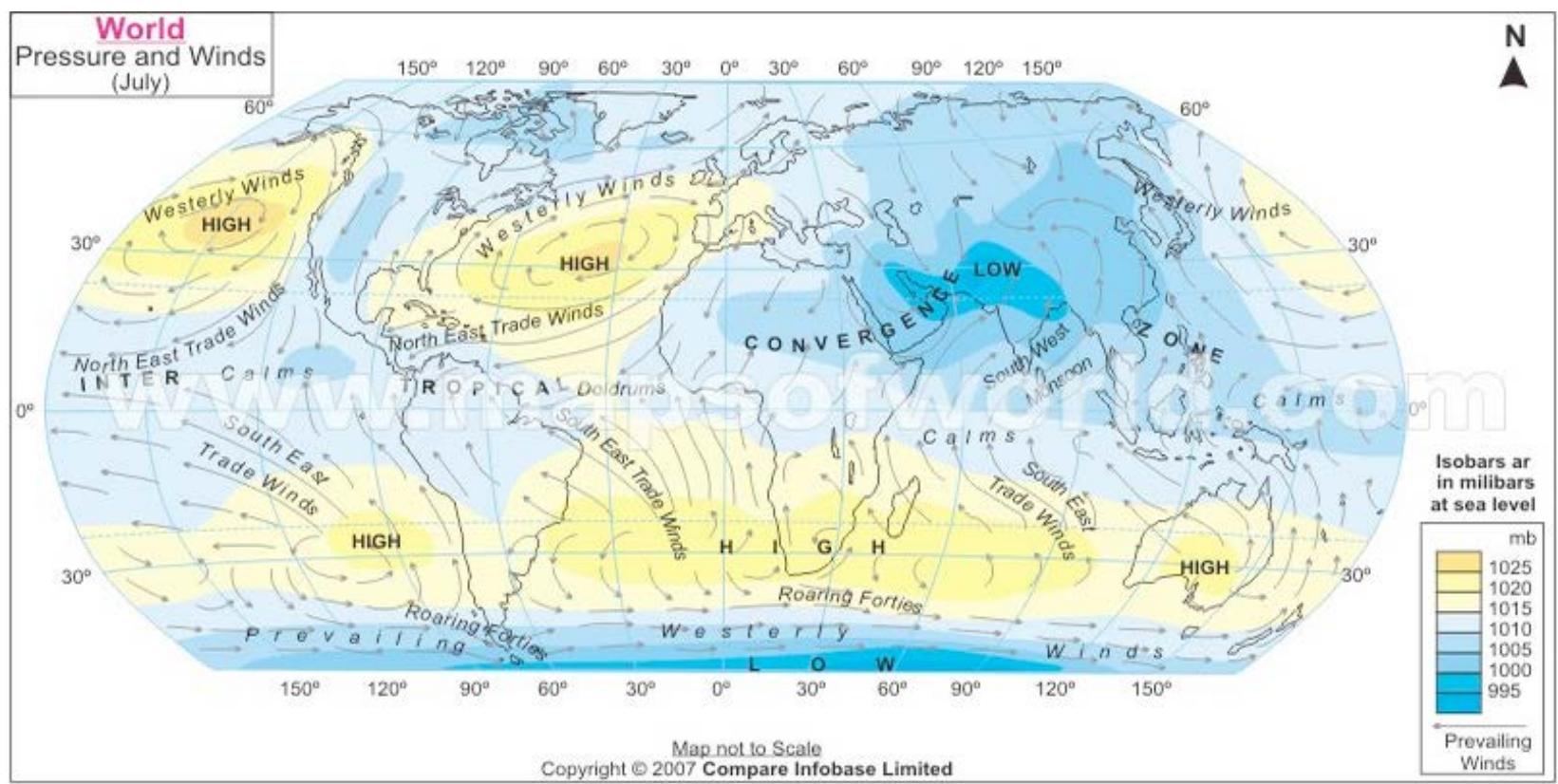

Figura 6 - Média das pressões atmosféricas para o mês de julho.

Fonte: Maps of the world.

A Figura 7 apresenta as Zonas de Convergência Intratropical (ZCITs) e sua ligação com as estações do ano, devido à mudança de posição do Sol em relação ao Equador da Terra. As zonas ilustradas são apenas uma média, pois o equilíbrio depende da quantidade de energia que o planeta recebe do Sol, que não é constante. Dessa forma, nosso clima, definido pela circulação atmosférica, é intimamente ligado à emissão de energia de nossa estrela, que determinará as secas ou as enchentes, estabelecidas pelas zonas de alta e baixa pressão ao redor do globo. Tudo depende de onde acontecerá o equilíbrio entre as massas de ar. Uma diminuição da quantidade de energia emitida pelo Sol e absorvida pela Terra poderá fazer com que as zonas de alta pressão fiquem mais próximas do Equador, ou melhor, em uma latitude (norte e sul) não a $30^{\circ}$, mais algo em torno de $25^{\circ}$. Se aumentasse essa energia, as zonas ficariam mais distantes, a uma latitude (norte e sul) em torno de $35^{\circ}$.
Aí, sim, as mudanças causariam grandes alterações no clima terrestre, fazendo diferir o clima de um ano para o outro.

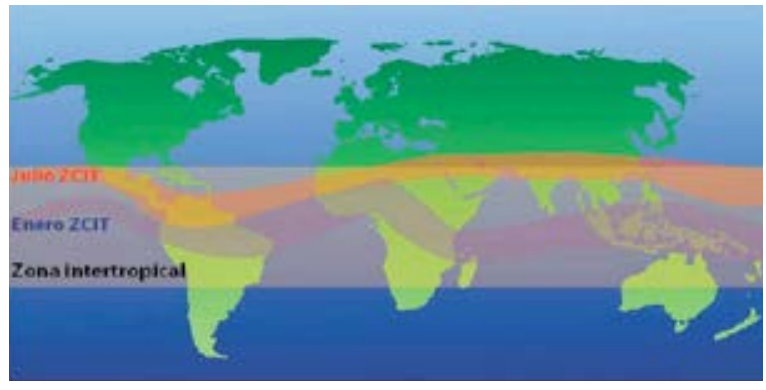

Figura 7 - ZCITs.

Fonte: $h$ ttp://www.dominicanaonline.org/diccionariomedioambiente/es/ verInformacion.aspx?id=1110

Nota: ZCITs são cinturões de baixa pressão formados pela convergência do ar quente e úmido das latitudes próximas ao Equador. Mudam de posição de acordo com as estações do ano, em alinhamento com a posição do Sol. 


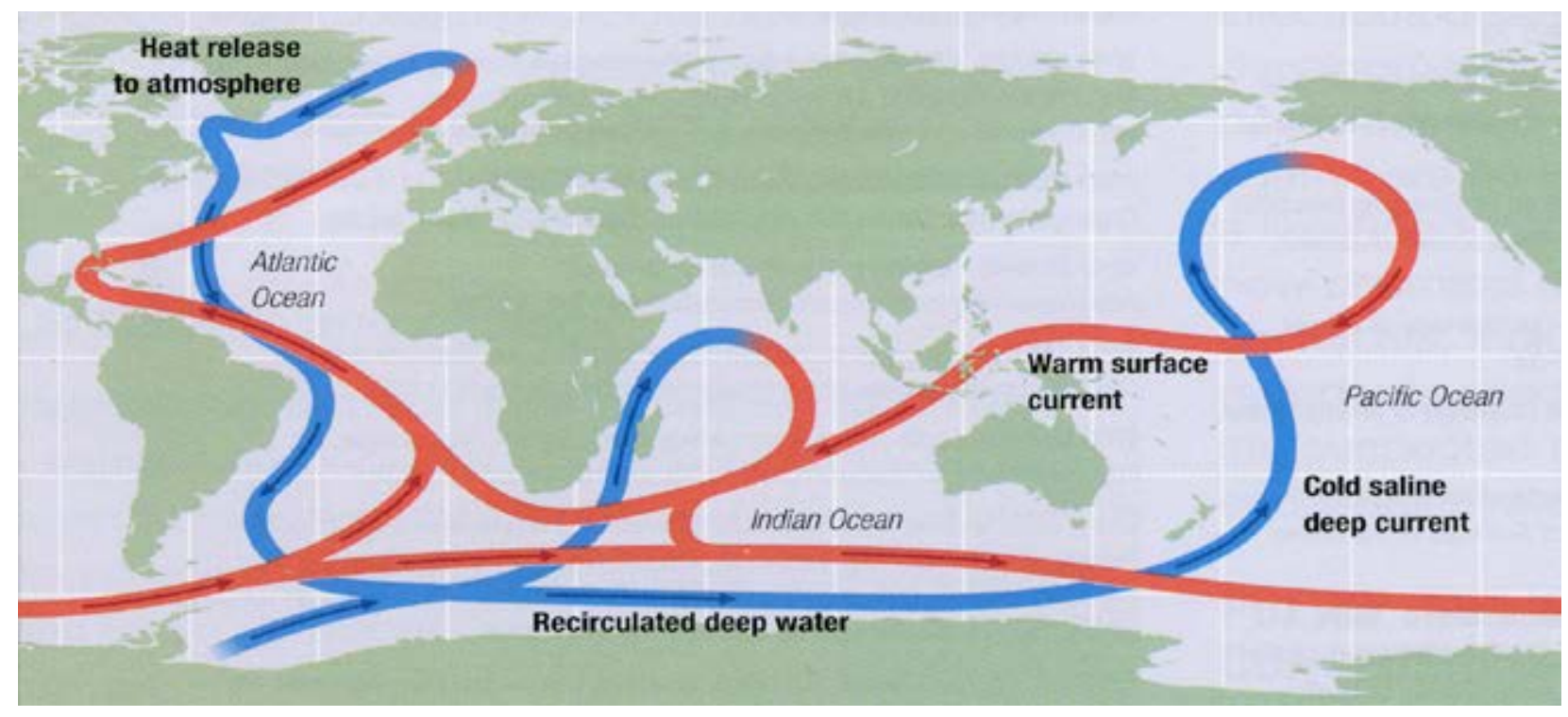

Figura 8 - Circulação oceânica, responsável também pela redistribuição de energia em nosso planeta.

Fonte: http://www.geol.umd.edu/sgc/lectures/climatepart2.html

A circulação oceânica também regula a temperatura em nosso planeta, conforme ilustra a Figura 8. Nela, podemos notar que a Grã-Bretanha está localizada mais ao norte do que a cidade de Nova lorque, porém é mais frio nesta cidade do que em Londres, localizado na latitude $51^{\circ} 30^{\prime}$ Norte. Isso se deve ao fato da corrente quente que chega do Golfo do México e atinge o oeste europeu. Nova lorque está localizada na latitude $42^{\circ} 08^{\prime}$ Norte, mais ao sul do que a cidade espanhola de Santiago de Compostela, localizada na latitude $42^{\circ} 52^{\prime}$ Norte, mas a cidade galega é mais quente que a norte-americana.

Agora, vamos voltar aos efeitos climáticos vivenciados atualmente no estado de São Paulo e sul de Minas Gerais. Como poderia o efeito do Sol afetar nosso clima?

Primeiramente, gostaria de contar a história da construção do Sistema Cantareira. Idealizado na década de 1960, previa a construção de cinco reservatórios em duas etapas. A primeira etapa foi iniciada em 1967 e concluída em 1974, com a construção dos reservatórios de Cachoeira, Atibainha, Juqueri (atual Paiva Castro) e Águas Claras, da Estação Elevatória de Santa Inês (EESI), além dos túneis 1, 2, 3, 4, 5 e 6. A outorga para a transposição das águas dos afluentes do rio Atibaia foi concedida por 30 anos, razão pela qual foi realizada sua renovação em 2004, por mais dez anos, que deveria ter sido revista em agosto de 2014. Devido à grave estiagem, a renovação foi postergada para outubro de 2015. Já a segunda fase, correspondente à construção dos reservatórios dos rios Jaguari e Jacareí, cujos volumes somados correspondem a $82 \%$ de todo o volume armazenado, foi iniciada em 1977 e concluída em 1982. No verão de $1982 / 83$, ocorreu o efeito El Niño, que provocou grandes precipitações nos estados de São Paulo, Paraná, Santa Catarina e Rio Grande do Sul. Choveu, em um ano, o equivalente à precipitação de dois anos. Assim, em menos de um ano foi possível o enchimento desses dois reservatórios. A partir daí, o Sistema Cantareira passou a operar em sua plenitude. A Figura 9 ilustra o Sistema Cantareira em suas duas fases de construção. 


\section{SISTEMA CANTAREIRA}

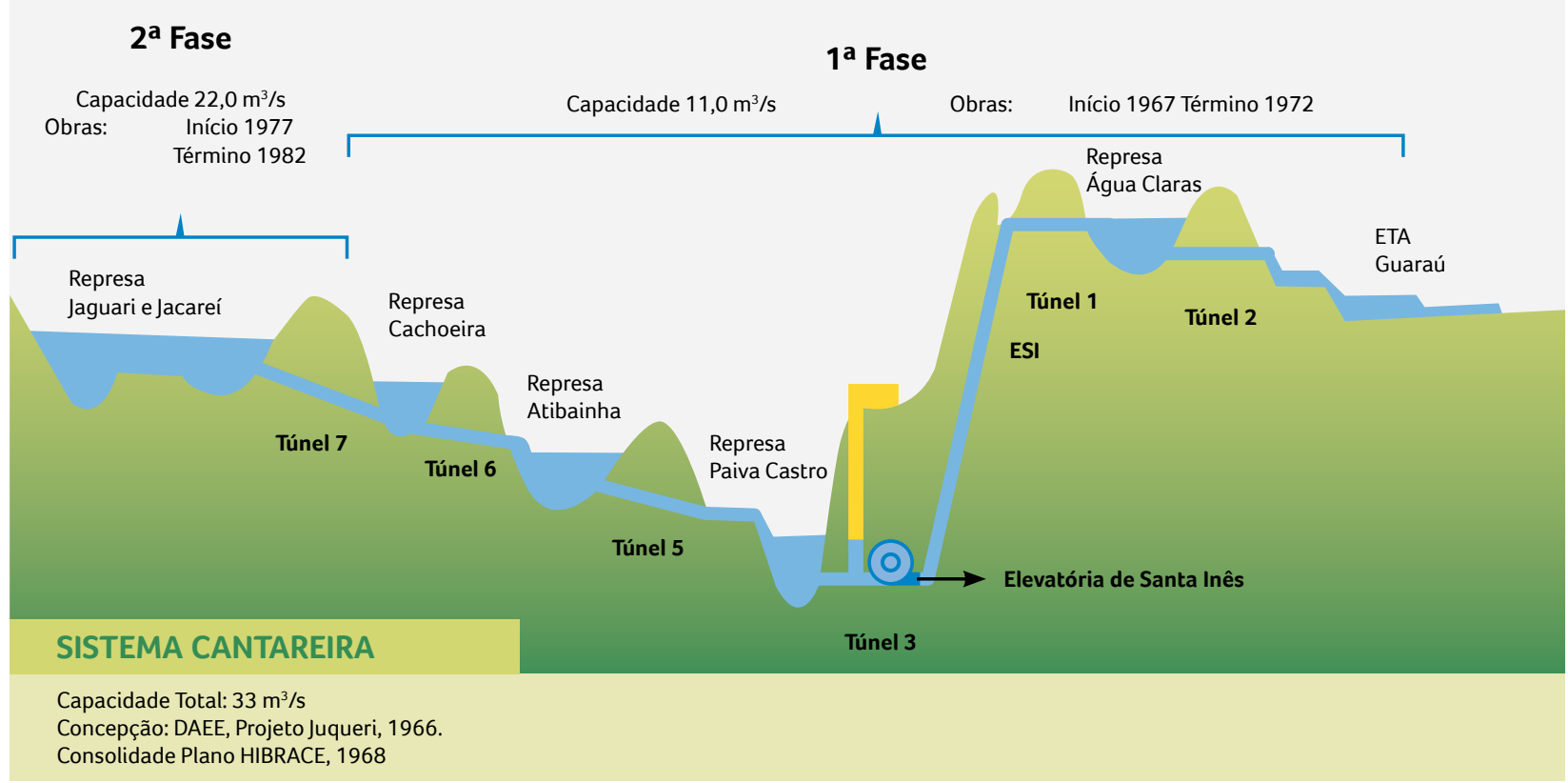

Figura 9 - Desenho esquemático do Sistema Cantareira.

Para dimensionar um reservatório, há a necessidade de conhecer o regime hidrológico da região em que será construído. As vazões são variáveis sazonais, ou melhor, no verão, são abundantes, porque no Sudeste brasileiro o verão é chuvoso e o inverso, seco, como já abordado a respeito da circulação atmosférica; no inverno, as vazões são baixas. A finalidade do reservatório é acumular o excesso de água no verão, para ser utilizado no período de estiagem. Então, as barragens têm dupla função: redução dos efeitos das enchentes no período chuvoso e regularização das vazões, para atendimento das demandas hídricas durante o período seco, aumentando a segurança hídrica de uma região.

As precipitações também são altamente variáveis em torno de sua média; em um ano podemos presenciar uma cheia muito grande e, no ano seguinte, passar por uma estiagem. Dessa forma, é de suma importância o conhecimento desses dados hidrológicos, tanto de chuvas quanto de vazão dos rios. Quanto maiores forem as extensões das séries históricas, mais acurados serão os projetos dos barramentos quanto à determinação de sua capacidade de regularização.

Vejamos o que aconteceu com o dimensionamento dos reservatórios do Sistema Cantareira. Os estudos para a elaboração dos projetos dos barramentos iniciaram na década de 1960, época em que não havia postos fluviométricos na região com longas séries históricas de registro de vazões; existiam apenas cinco postos, com séries curtas, apenas um com mais de 30 anos, todos localizados no rio Atibaia, com extensão média inferior a 22 anos.

A Figura 10 ilustra na barra do tempo as precipitações totais anuais para o posto pluviométrico 
instalado no Instituto Agronômico de Campinas (IAC), cuja série histórica inicia-se no final do século XIX. Na figura, podemos observar que o período compreendido entre os anos de 1933 e 1969 foi o mais seco de toda a série histórica. Também verificamos que as precipitações médias para os anos anteriores a 1933 e posteriores a 1970 são maiores que aquela observada no período entre 1933 e 1969. Por que essa informação é importante? Ela é importante para compreendermos que a variabilidade climática é uma realidade e um processo natural cíclico, não tendo o homem qualquer poder de alterá-la.

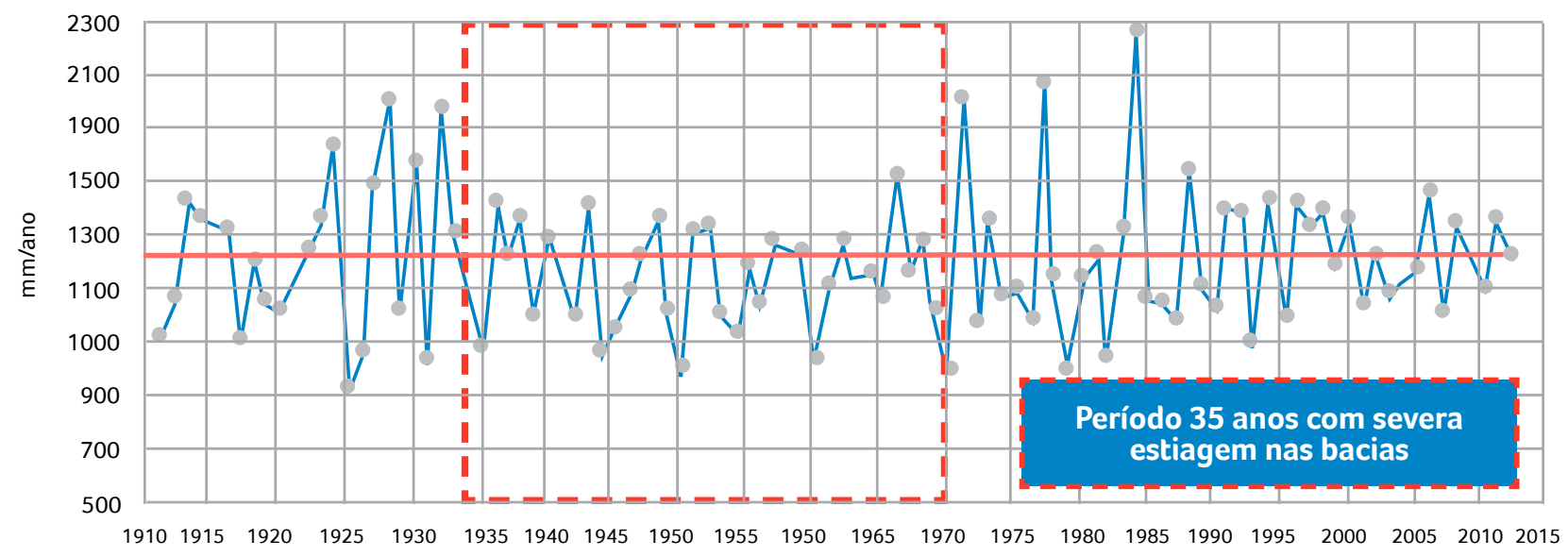

Figura 10 - Série histórica de precipitações do posto pluviométrico instalado no IAC, no município de Campinas, coração da bacia do rio Piracicaba, no estado de São Paulo.

Vejamos mais argumentos para nossa afirmação anterior. Há um efeito cíclico de longo período difícil de perceber, uma vez que nossas séries históricas, em sua maioria, são inferiores a 40 anos de extensão, mas esses comportamentos cíclicos podem ser detectados nas séries hidrológicas mais longas.

No estudo elaborado pelo Consórcio HIDROPLAN, intitulado Plano integrado de aproveitamento e controle dos recursos hídricos das bacias do Alto Tietê, Piracicaba e Baixada Santista, de 1995, foi realizada uma análise da disponibilidade de água nas bacias que compõem atualmente a macrometrópole paulista. $O$ estudo hidrológico realizado recuperou/complementou as vazões médias mensais do rio Piracicaba, em Piracicaba, do rio Jaguari, em Fazenda Buenópolis e Usina Ester, e do rio Atibaia, em Atibaia, Bairro da Ponte e Acima Paulínia, para o período de janeiro de 1930 a dezembro de
1993. Tal estudo foi possível porque esses postos fluviométricos, criados na ocasião da construção do Sistema Cantareira, já dispunham de uma série histórica de mais de 20 anos, permitindo a definição das séries de vazões naturais médias mensais.

$\mathrm{Na}$ Nota Técnica Conjunta ANA/DAEE-SP, de 2004, o estudo do Consórcio HIDROPLAN foi estendido de janeiro de 1994 até dezembro de 2003, aumentando as séries de vazões em dez anos. 0 estudo subsidiou, assim, as negociações para a aprovação do pedido de outorga do Sistema Cantareira e para a definição das condições de operação dos seus reservatórios, constantes da Portaria DAEE $n^{\circ} 1.213$, de 6 de agosto de 2004.

Ressalta-se que nenhum desses dois estudos, tampouco o estudo de concepção dos reservatórios do Sistema Cantareira, levaram em conside- 
ração os efeitos cíclicos de longos períodos. Esses períodos longos mais secos e úmidos se sucedem ciclicamente e são conhecidos como efeito José. Outro efeito existente é o Noé, observado no verão de 1982/83, como já mencionado, que foi capaz de encher os reservatórios de Jaguari e Jacareí em menos de um ano, uma vez que a chuva nesse verão foi equivalente ao dobro da média histórica para o período. No estudo original de concepção do Sistema Cantareira, destaca-se que a falta de ferramentas computacionais - não disponíveis naquela época (1960-1975) - e os registros disponíveis não permitiram a detecção desses efeitos, por não estarem caracterizados e também por somente terem sido descobertos em 1968, no estudo dos estatísticos Mandelbrot e Wallis (1968).

A ocorrência de registros fluviométricos temporais de um longo período seco, os quais embasaram os estudos de dimensionamento originais dos reservatórios do Sistema Cantareira, pode ter levado a um aumento da exposição ao risco de enchentes a jusante dos reservatórios do sistema, visto que foi dimensionado com os dados históricos de um período prolongado de baixas vazões e operado em um período prolongado de altas vazões.

\section{EFEITOS NOÉ E JOSÉ}

Em artigo publicado na Water Resources Research, em 1968, Benoit B. Mandelbrot e James R. Wallis estudam os dados fluviométricos históricos de alguns dos grandes rios do mundo, em particular, do Nilo, no Egito. Eles identificam padrões recorrentes, os quais, em alusão ao comportamento de personagens bíblicos do livro de Gênesis, batizam como efeito José e efeito Noé.

O efeito José está relacionado ao personagem bíblico José do Egito, que interpretou o sonho das vacas gordas e magras como um período de sete anos de colheitas fartas e em abundância, trazendo prosperidade para o Egito, seguidos de sete anos de secas, que trariam fome e miséria. Segundo o texto bíblico, a interpretação foi correta e o fato foi observado: sete anos de boas colheitas seguidos de sete anos de seca e fome. Esse efeito descreve a "persistência" dos fenômenos, no caso, as chuvas.

Os autores dissertam que as tendências tendem a persistir, ou seja, é provável que um lugar castigado por secas recorrentes continue a sofrer com elas; já em locais em que há chuvas em abundância, é provável que elas perpetuem. Em outras palavras, as coisas tendem a ficar do jeito que têm sido nos últimos tempos. Definem que "um período longo não usual de precipitações (altas ou baixas) pode ser extremamente longo" (MANDELBROT; WALLIS, 1968). Nesse caso, podemos interpretar o sentido de "longo" como um período de 30 a 50 anos. Os autores afirmam ainda que "os modelos atuais de hidrologia estatística não consideram um ou outro efeito e devem ser substituídos" (MANDELBROT; WALLIS, 1968), porque os testes estatísticos de tendências misturam esses períodos e a informação se perde.

O efeito Noé está relacionado à história do grande dilúvio, sendo a Noé atribuído o crédito de ter construído a arca. Esse efeito descreve a "descontinuidade". Mandelbrot e Wallis (1968) afirmam que, quando algo muda, pode ser de forma abrupta; em suas palavras: "Nós designamos como Efeito Noé ao fato que uma precipitação extrema pode ser realmente muito extrema, [...]"(MANDELBROT; WALLIS, 1968). Isso equivale a dizer que se pode esperar o inesperado.

De acordo com o escritor científico James Gleick, "os efeitos Noé e José empurram para direções diferentes, mas se eles se somam levam a isto: as tendências da natureza são reais, mas elas podem desaparecer tão rapidamente como apareceram". Eles são "quase ciclos" ou "ocorrem" em séries de tempo cíclicas, que se parecem, mas não são iguais, visto que os efeitos não ocorrem em uma base previsível regular.

Outros estudos confirmam o comportamento do efeito José. Por exemplo, consoante Djane Fonseca 
da Silva (2013, grifo do autor), em Efeito de José e Noé nas cotas do rio São Francisco:

O Efeito do José e Noé é observado em vários rios da América do Sul e da África; na América do Sul foi observado aumento de vazão após 1970 enquanto que na África, ocorreu o contrário.

[...] testar a hipótese do Efeito do José e Noé sobre variações de cotas de rios nesta bacia hidrográfica. Os dados diários de cotas de rio utilizados foram obtidos através da Agência Nacional das Águas (ANA) para o período de dados de 1938-2010.

Concluiu-se que o efeito José e Noé também ocorreu na bacia hidrográfica do rio São Francisco, principalmente nas sub-bacias do ASF e MSF, não sendo tão marcantes no SMSF e BSF, as quais também sofrem intervenção de Sobradinho desde 1979.

Rios da América do Sul e da África já apresentaram esse comportamento, como citado por Tucci e Clarke (1980) e Collischonn et al. (2001), onde relataram que na América do Sul foi observado aumento de vazão após 1970 enquanto que na África ocorreu o contrário.

Tucci e Braga (2003) citaram que desde 1970 as regiões centro-oeste, sul e sudeste apresentaram vazão média cerca de $30 \%$ superior a do período anterior. Segundo os autores, o aumento de vazões ocorre, pelo menos parcialmente, como consequência de um aumento simultâneo, mas menos intenso, das precipitações da mesma região do Brasil.

Simultaneamente, em algumas regiões da África (exemplo, a Bacia do Congo e África subsaariana), passaram por período menos úmido do que períodos anteriores, o que ocasionou redução de vazões e cotas de rios (Tucci e Braga, 2003).

Já Tucci (2011), dá como exemplo as diferentes variações observadas no rio Paraguai e no Lago Vitória. A série de Ladário no rio Paraguai apresentou cotas máximas anuais de 1900 a 1960, quando flutuou perto de 4,0 m, enquanto que no período de 1960 a 1973, chegou um pouco acima de 2,0 m. Depois de 1974 a 2000 atingiu cerca de 5,0 m. No lago Vitória, na África, o período de níveis foi o oposto ao do rio Paraguai, cheia entre 1960 e 1973 e níveis muito abaixo no restante.
Diante do exposto, podemos esperar a continuação do que está acontecendo, mas também devemos esperar o inesperado. Mas por que, em nossa sociedade moderna e com toda nossa tecnologia, ainda temos que esperar o inesperado e não conseguimos ainda prevê-lo? A resposta a essa questão talvez esteja sob nossos pés, ou melhor, sobre nossas cabeças: o Sol. Assim, vamos falar sobre os ciclos solares.

Já foi discutido sobre a quantidade de energia que a Terra recebe por metro quadrado por segundo de nosso Sol. Agora, vamos ver o tempo de resposta desses estímulos ou dessa energia para a mudança da temperatura de nosso planeta. A Figura 11 ilustra duas curvas: uma descreve os comprimentos preditos para os ciclos solares e a outra, a temperatura na superfície da Terra. Pode-se observar que existe um atraso, um delay, entre elas, o qual pode ser percebido entre dez e 18 anos.

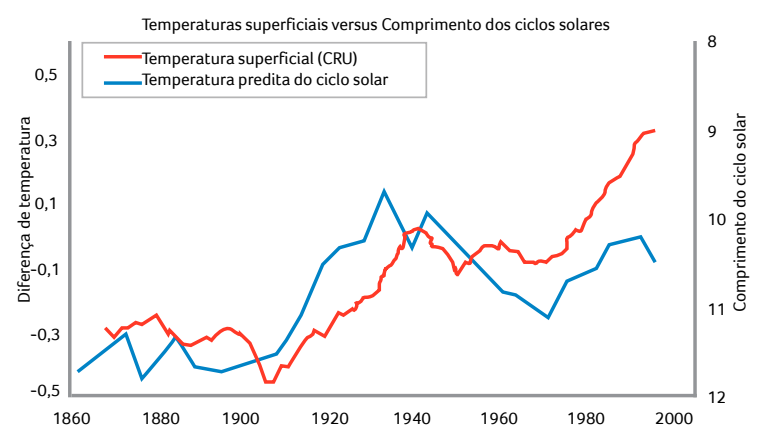

Figura 11 - Temperaturas superficiais comparadas com o comprimento dos ciclos solares desde 1858. Fonte: http://www.brighton73.freeserve.co.uk/gw/solar/solar.htm.

A Figura 12 ilustra a temperatura média da Terra e suas tendências de 2001 até 2013; nela, verificamos a tendência de diminuição da temperatura média global nos últimos anos. A temperatura média máxima da Terra ocorreu em 1998 e vem decaindo desde então. Já a Figura 13 mostra a variação das temperaturas médias da superfície da terra, dos oceanos e a média global dos últimos 
130 anos. Verifica-se que a temperatura máxima média global média ocorreu em 1998, tendo invertido sua tendência de crescimento para decrescimento, padrão verificado várias vezes ao longo dos últimos 130 anos. Pode-se observar, ainda, que havia uma tendência de decrescimento da temperatura, considerando o período de 1930 a 1970, que coincide com o período mais seco de nossos registros no caso das bacias dos rios Piracicaba, Capivari e Jundiaí. A partir da década de

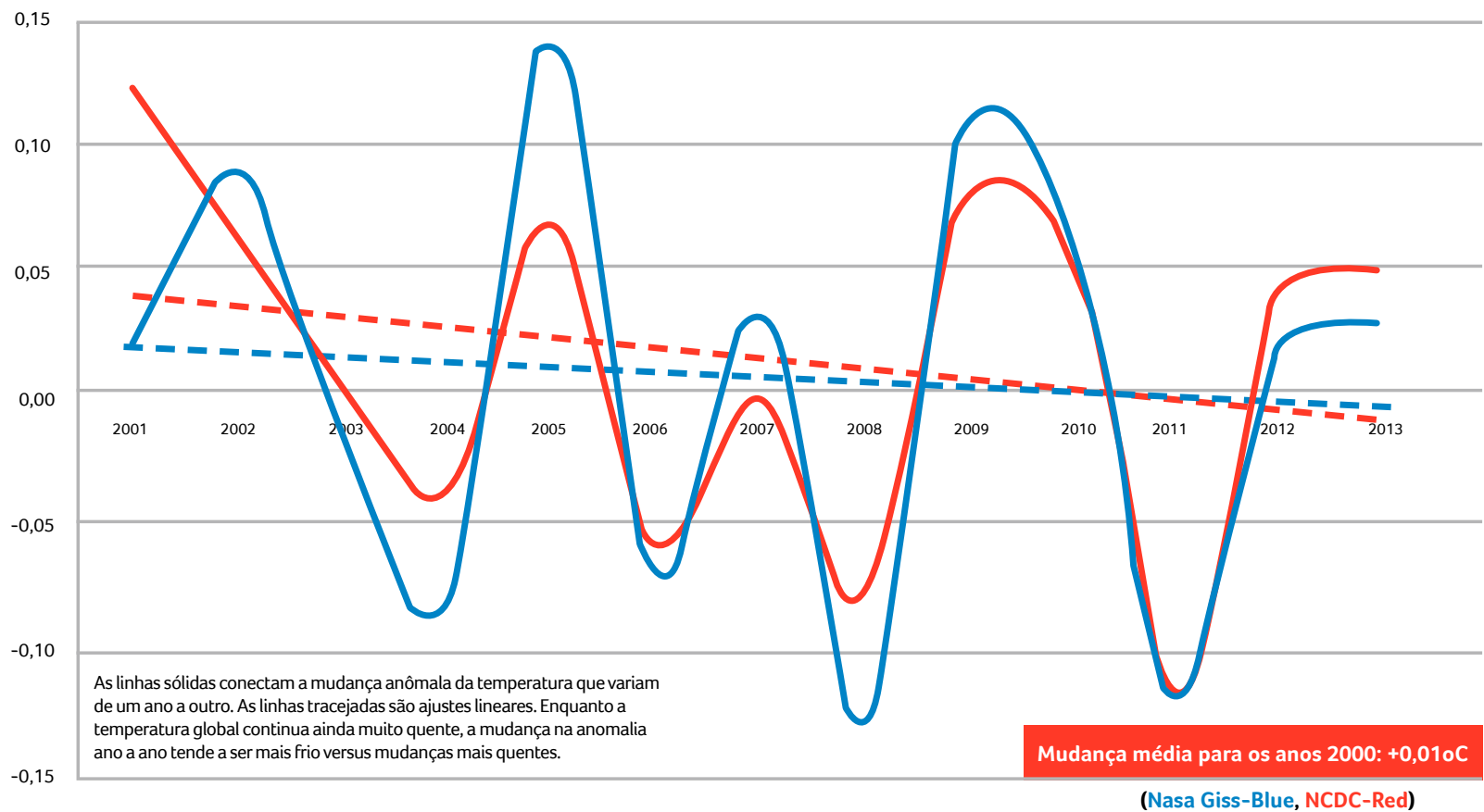

Figura 12 - Anomalia na mudança de temperatura anual global em Celsius.

Fonte: http://www.brighton73.freeserve.co.uk/gw/solar/solar.htm.

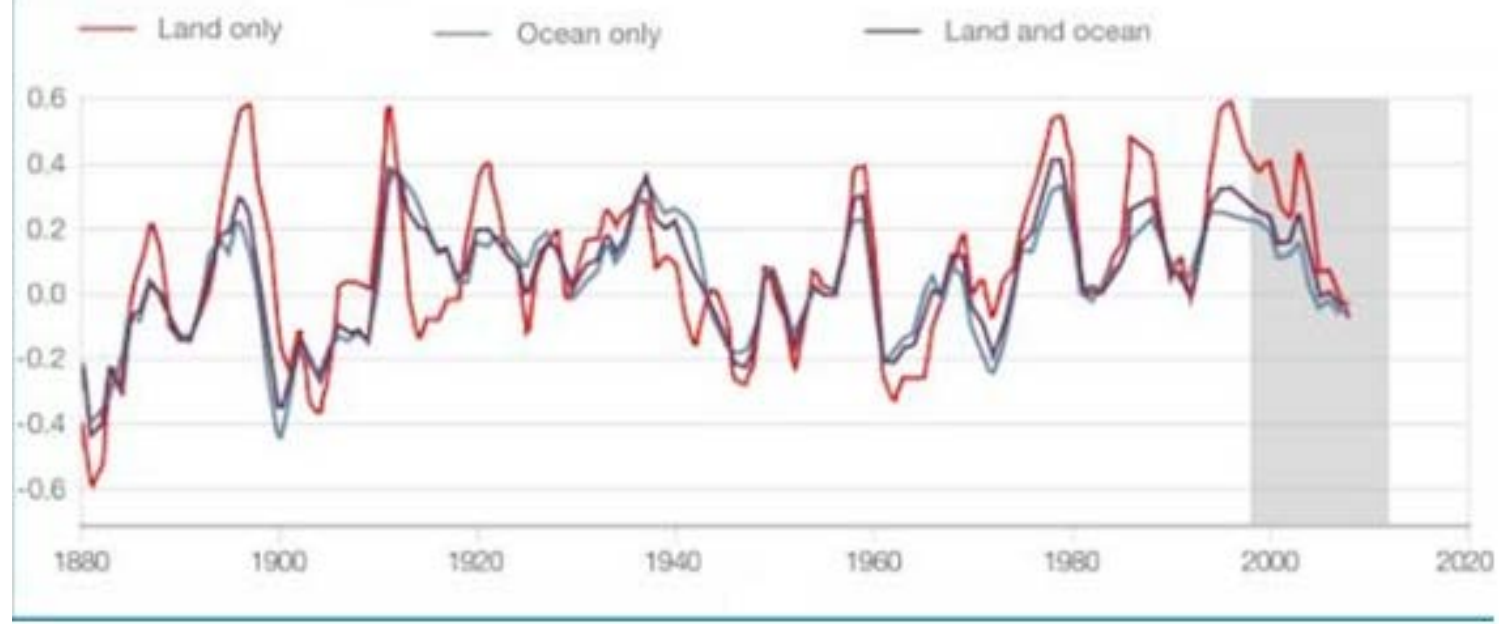

Figura 13 - Variação da temperatura média na terra, oceano e média global ao longo das últimas décadas. Fonte: $h$ ttp://www.bbc.com/news/science-environment-24173504 (Met Office). 
1970, as temperaturas cresceram e aumentaram as precipitações nas regiões Sudeste e Centro -Oeste. Coincidência?

Vamos tentar explicar esses fenômenos à luz de outra teoria, a teoria dos ciclos solares.

Nossa civilização aprendeu, ao longo dos séculos, as razões pelas quais existem as marés. Atualmente, sabemos que elas são o efeito da atração da Lua, do Sol, dos outros planetas de nosso Sistema Solar e do centro da galáxia, na ordem de maior para menor efeito. Para estudos de marés, consideram-se diferentes períodos, como as duas marés diárias (12h), as marés de Luas Cheia e Nova (14 dias) e outros ciclos de maiores períodos. Assim também funciona o nosso Sol, com diferentes ciclos, que podem se sobrepor uns aos outros.

O clima terrestre depende de um equilíbrio delicado entre diferentes fatores e não se pode compreendê-lo prendendo-se apenas a um processo simples e isolado, como o efeito estufa provocado pela emissão de carbono na atmosfera. Todos esses processos devem ser analisados em conjunto.

Segundo Guerrero (2009), a temperatura média da Terra depende principalmente do brilho do Sol e da quantidade de radiação que alcança nosso planeta, a qual está diretamente relacionada com as manchas solares. Em períodos de pouca atividade, o número de manchas solares é escasso ou inexistente, enquanto, nas épocas de números máximos de manchas, elas podem chegar a 200. Em 1843, Heinrich Schwabe observou que o número de manchas registradas não era constante ao longo do tempo, mas aumentava ou diminuía em ciclos de aproximadamente 11 anos. Isso porque sua visibilidade é afetada pela rotação diferencial do Sol, que possui durações distintas em cada latitude. Dado que o Sol é a fonte de energia para a Terra, parece possível que, quando sua atividade diminui e reduzem-se as manchas solares, ocorra um efeito de esfriamento do clima no planeta.
Ainda segundo o autor, existem quatro ciclos solares que são mais ou menos importantes dependendo da duração dessa atividade. Essas variações na atividade solar foram e são estudadas sobre uma base de análise do carbono 14 (14C), isótopo que se forma pela ação dos raios cósmicos sobre o nitrogênio atmosférico (GUERRERO, 2009).

O primeiro e mais famoso ciclo solar, assim mencionado por Guerrero (2009), é o de Schwabe, cuja duração varia entre oito e 13 anos, com uma média de 11 anos. Considerado o spot solar, o ciclo foi descoberto por Heinrich Schwabe (1789-1875), mediante a observação da aparição das manchas solares. $\mathrm{O}$ autor afirma que este é um ciclo em que o Sol atravessa todas as suas etapas de atividade. Começa do mesmo modo que acaba, com uma atividade muito escassa, enquanto, na zona central, existe um máximo, sendo a atividade solar elevada. Nesses ciclos solares, podem ocorrer variações de luminosidade e ventos solares ou no campo magnético, mas ambos estariam relacionados entre si.

No mínimo do ciclo de Schwabe, a Terra receberia menos radiação ultravioleta, o que resultaria em uma redução na produção de ozônio na estratosfera; no máximo do ciclo, a produção de ozônio aumentaria de 1 a $2 \%$. Essa variação na concentração de ozônio na estratosfera contribuiria para o efeito estufa, mediante a absorção de raios infravermelhos, e, portanto, haveria uma diminuição na temperatura durante o mínimo de Schwabe e vice-versa, de forma que esses efeitos seriam compensados ao longo do tempo.

O segundo ciclo, o de Hallstattzeit, também foi confirmado pela análise da concentração de 14C e dados climáticos. Alguns pesquisadores associam-no às atividades solares, enquanto outros creem que seria um tipo de oscilação do sistema oceano-atmosfera. Este ciclo teria um período de 2.300 anos e seu próximo mínimo deverá ser alcançado por volta do ano 2800 e seu mínimo, somente em 3950. Seu mínimo coincidiu com o mínimo de Maunder, ocorrido entre o final do sé- 
culo XVII e o início do século XVIII (1645-1715). O mínimo de Maunder ficou conhecido como a pequena idade do gelo, pois, durante sua ocorrência, foi responsável por invernos mais rigorosos.
No terceiro ciclo, conhecido como ciclo de Suess, a análise do $14 \mathrm{C}$ indica uma periodicidade variando de 150 a 200 anos. As datas de ocorrência dos mínimos de Oort, Wolf, Sporer, Maunder e Dalton,

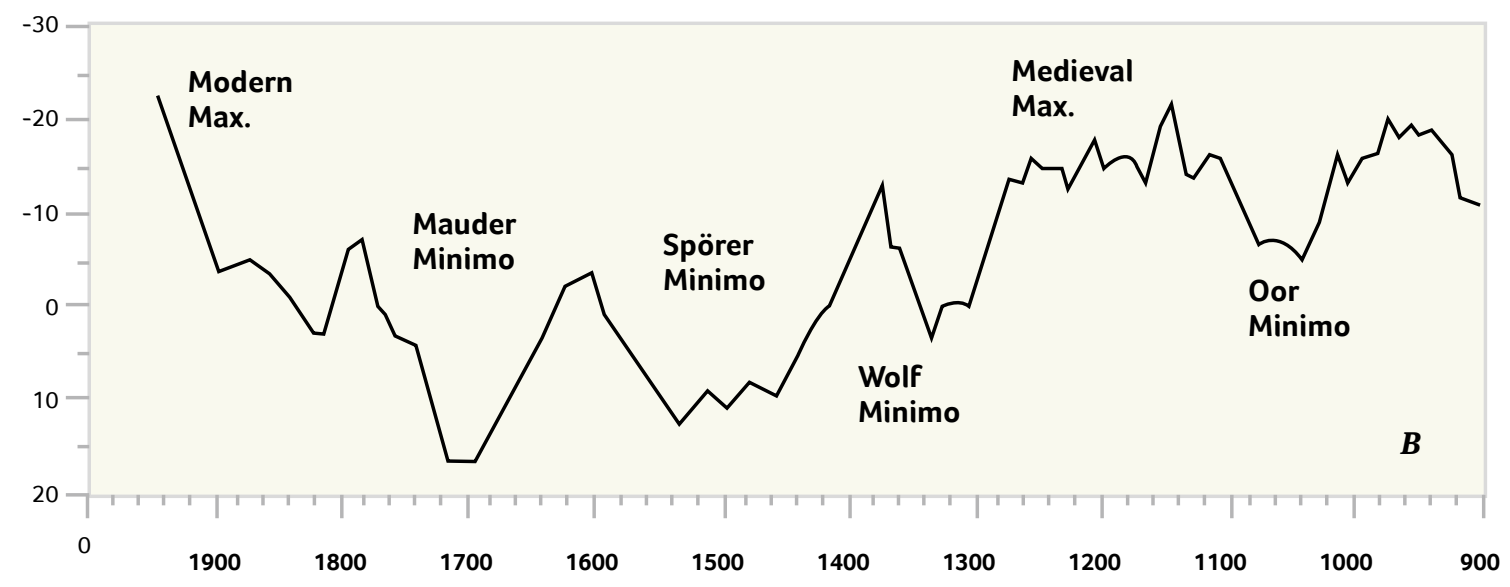

Figura 14 - Mínimos durante o último milênio.

Fonte: http://www.astrosafor.net/Huygens/2009/78/huygens-78-miguel.pdf.

apresentados na Figura 14, sugerem uma periodicidade aproximada de um a dois séculos. Este ciclo conduz a uma variabilidade de amplitude no ciclo de Schwabe, como mencionado por Guerrero (2009), quando se comparam os ciclos de 1715 e de 1958.

O quarto e último ciclo mais importante, o de Gleissberg, teria um período variando de 67 a 100 anos e foi descoberto por Gleissberg, em 1958. Este ciclo teria efeitos diretos sobre o ciclo de Schwabe e estaria relacionado com a variação do diâmetro solar de 0'5" de arco, com um período aproximado de 900 dias ou 27 meses da mesma fase, e também com o movimento do Sol ao redor do baricentro de massa do Sistema Solar. O máximo de Gleissberg ocorreu por volta de 1984 e foi o primeiro de uma longa sequência de máximos relacionados com as fases zero em um ciclo de 166 anos. Seus próximos máximos deverão ocorrer aproximadamente em 2069, 2159 e 2235. Tem-se observado que, durante a metade deste ciclo, o número de manchas solares é bastante superior ao da outra metade.

Podemos fazer a seguinte análise: na Figura 11, verificamos que a máxima temperatura da superfície da Terra ocorre entre dez e 18 anos do máximo comprimento do ciclo solar. O máximo de Gleissberg ocorreu em 1984 e a máxima temperatura registrada, em 1998, 14 anos depois. Mais uma coincidência? 


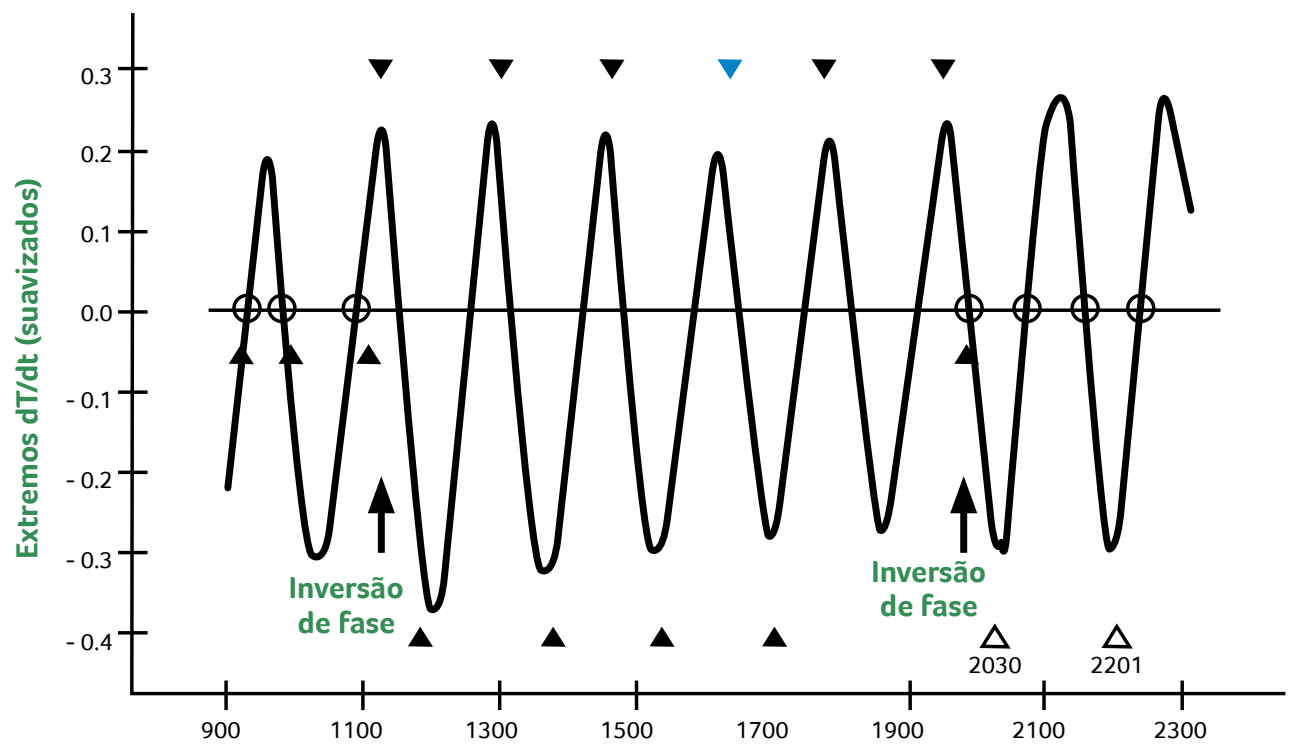

Figura 15 - Ciclo de Gleissberg.

Fonte: $h$ ttp://www.astrosafor.net/Huygens/2009/78/huygens-78-miguel.pdf.

A Figura 15 ilustra o ciclo de Gleissberg, estando seu próximo mínimo previsto para ocorrer por volta do ano 2030. Se considerarmos 14 anos para o reflexo desse mínimo na temperatura da Terra, 2044 será o ano mais frio; a partir dele, as temperaturas novamente irão se elevar, sem qualquer interferência com a concentração de dióxido de carbono.

Quase todos os mínimos de Gleissberg depois do ano 300 d.C., como, por exemplo, 1670, 1810 e
1895, coincidem com climas muito frios no Hemisfério Norte, enquanto seus máximos ocorrem em climas mais quentes, como, por exemplo, os anos de 1130 (ótimo climático medieval) e 1998 (aquecimento global antropogênico).

Dessa forma, analisando diferentes dados climatológicos em réguas de longos períodos de tempo, encontraremos comportamentos cíclicos. Nesse sentido, a Figura 16 apresenta a variação do Índice

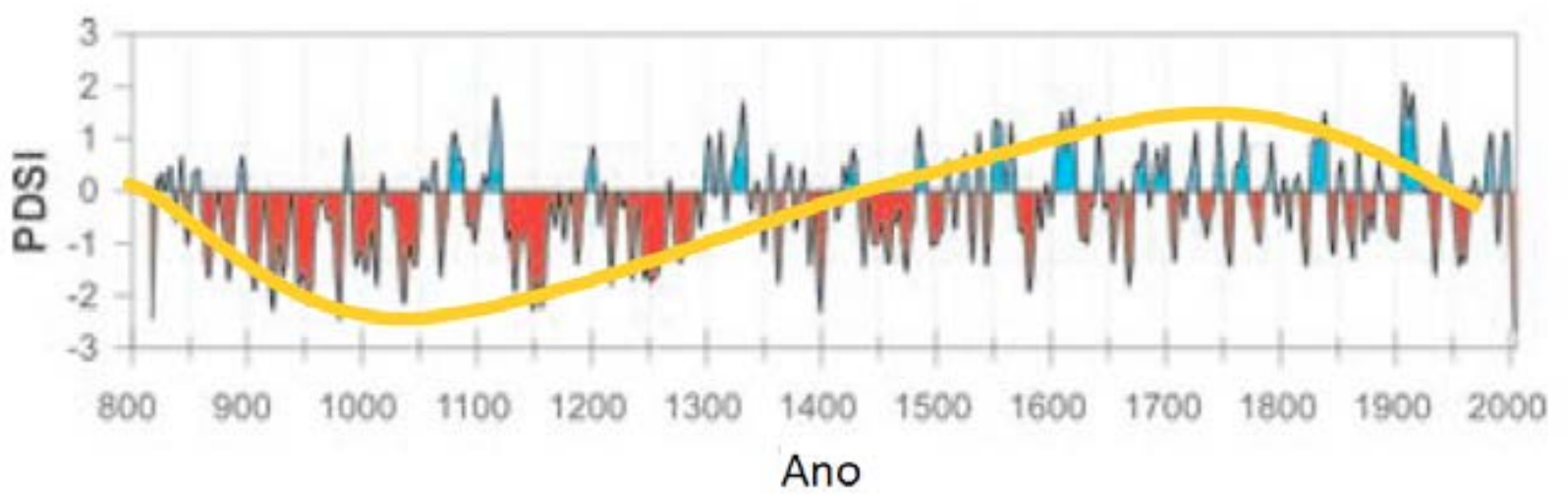

Figura 16 - PDSI para o Oeste americano.

Fonte: World Climate Report (2005). 


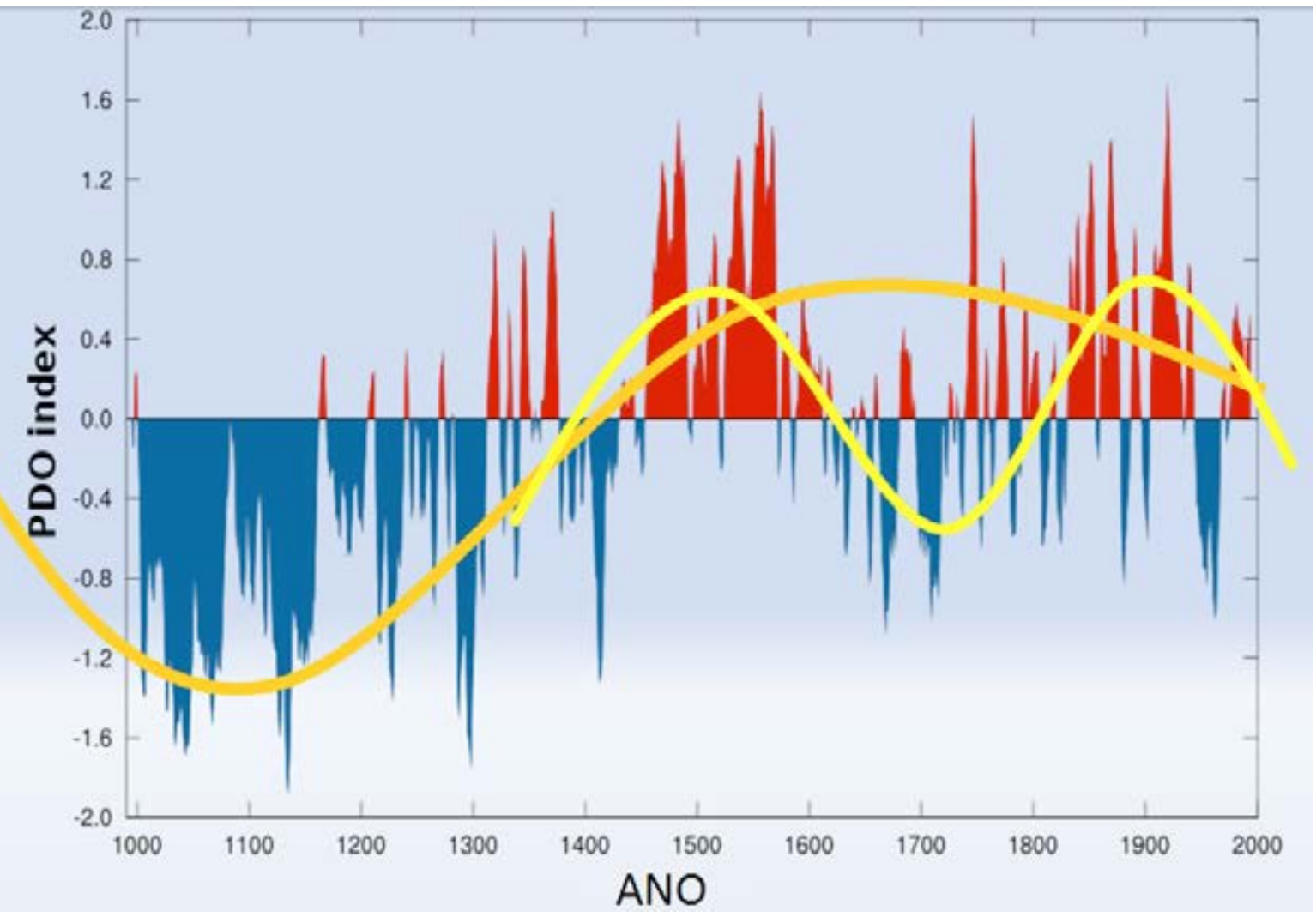

Figura 17 - Índice da ODP.

Fonte: http://en.wikipedia.org/wiki/Pacific_decadal_oscillation.

de Severidade de Secas de Palmer (PDSI), em uma régua de 1.200 anos, para o Oeste americano, em que valores negativos indicam períodos mais secos e positivos, períodos mais úmidos. Já a Figura 17 mostra dados a respeito da Oscilação Decadal do Pacífico (ODP), em que encontramos não um, mas dois ciclos distintos.

Na Figura 18, estão apresentadas as séries históricas de vazão do rio Colorado. Há um período observado compreendendo os últimos 100 anos e as vazões desde o ano 800 foram recuperadas por meio de técnicas de 14C. Na sequência, foi montada uma série com a somatória de três outras qua- se cíclicas, cujos períodos variam próximos a 11, 80 e 170 anos, para simular seu comportamento e superposição. Para melhorar a visualização, foi somada a elas a constante 100 , a fim de limpar a série resultante da poluição visual. O resultado representa bem o comportamento das vazões do rio Colorado, nos Estados Unidos. Observa-se, nessa série artificial, que os máximos e mínimos podem variar, representando com bastante similaridade o efeito natural observado. Dessa forma, a teoria dos ciclos solares consegue explicar muito melhor o efeito natural do clima que aquela do aquecimento global de origem antropogênica. 


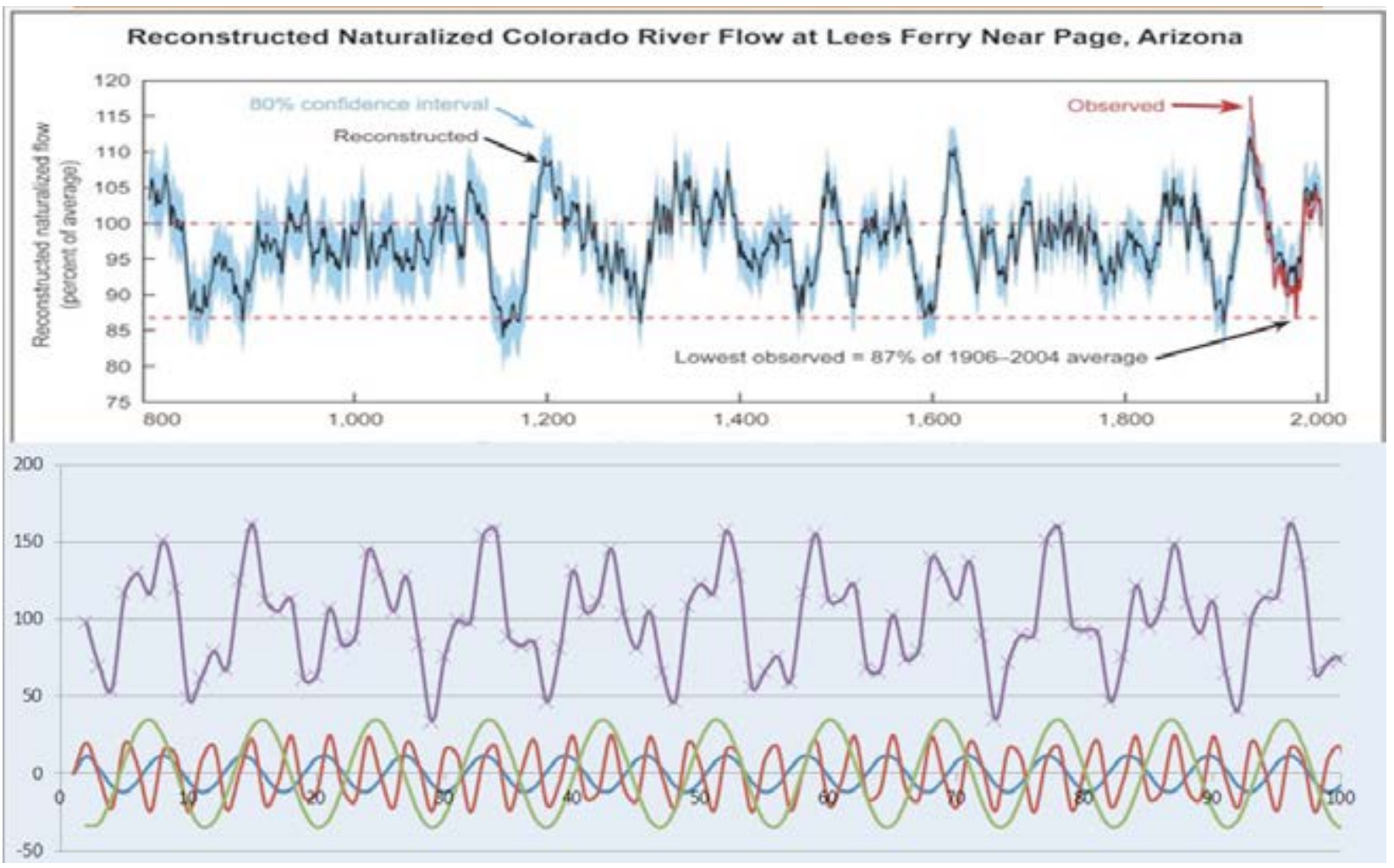

Figura 18 - Vazões naturais e reconstituídas do rio Colorado, Arizona. Fonte: $h$ ttp://www.southwestclimatechange.org/figures/past_flows.

Para terminar nossos argumentos, vamos comparar os efeitos do clima em dois anos distintos: 1953 e 2014. Em 1953, ainda não havia internet e as informações demoravam muito mais tempo para ser noticiadas ou simplesmente eram esquecidas. Há 61 anos, no Brasil, havia seca no Nordeste, Sudeste e Centro-Oeste, como também ocorreu a maior enchente do rio Amazonas. O Oeste americano também sofria com a seca e a Europa, com as enchentes - a Holanda foi o país europeu mais afetado naquele ano. Na China, uma seca, em toda a década de 1950, dizimou mais de 30 milhões de pessoas de fome; já o Japão sofria com as enchentes.
Ademais, a concentração de dióxido de carbono era muito menor que a atual e ainda não tinha sido construída a Transamazônica; dessa forma, esses fenômenos não poderiam estar relacionados com a ação humana, uma vez que a Floresta Amazônica continuava virgem. A industrialização no Brasil ainda engatinhava, havia muito pouca poluição; nosso país era agrário e $80 \%$ da população era rural. Qual é a explicação para esses fenômenos?

Em 2014, observamos os mesmos efeitos climáticos nas mesmas regiões. Coincidência? Não, não creio. Parece-me mais um padrão, que pode ser 
explicado pela variação na emissão de energia de nossa estrela maior, o Sol.

A Figura 19 faz um paralelo das regiões mencionadas nesses dois anos. Qual é a explicação? A resposta é uma só: ignorância! Ainda desconhe- cemos nosso planeta e como ele funciona. Temos um caminho para novas pesquisas, não cabendo a um engenheiro civil como eu, mas, sim, aos astrofísicos e físicos solares, tentar comprovar ou rejeitar essa hipótese.
มงเาม

Imagens impressionantes:A Invasão dos flagelos da seca em Surubim, 1953.

A seca de 1953,Padre Ferreira Lima ajuda flagelados.

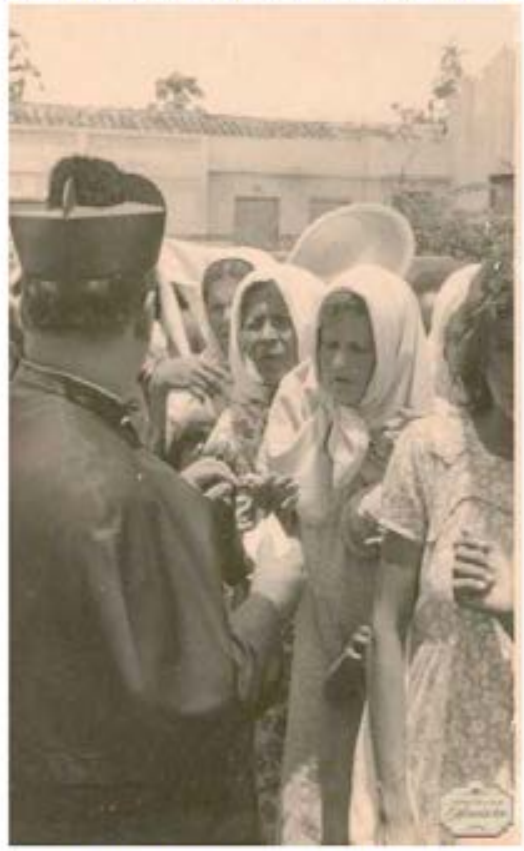

observe a expressoso de sofrimento das pessass na ffotoi.
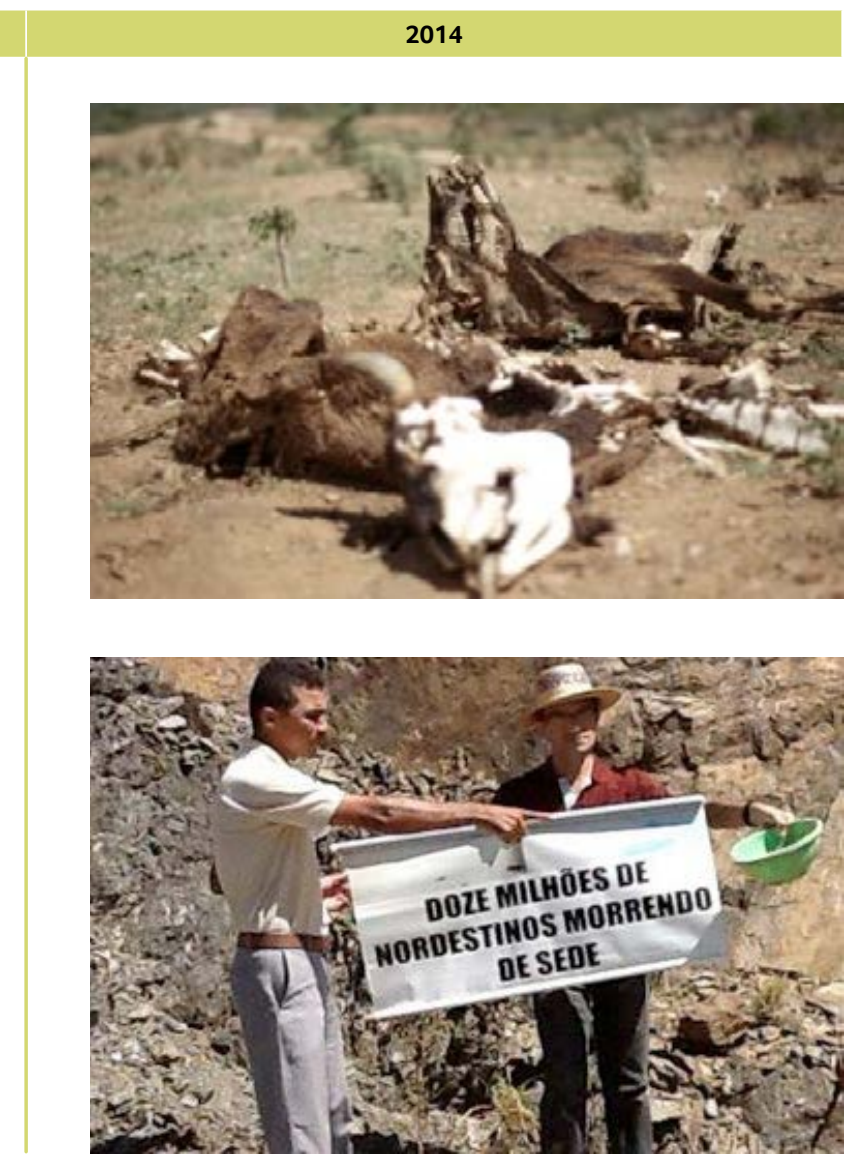

OEstado de SPrelo - 27तtiss

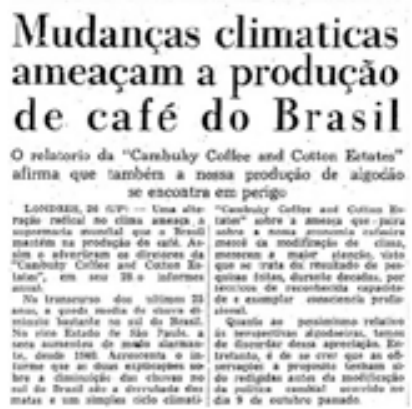

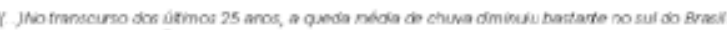

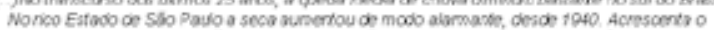

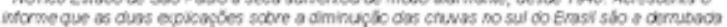

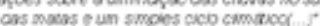

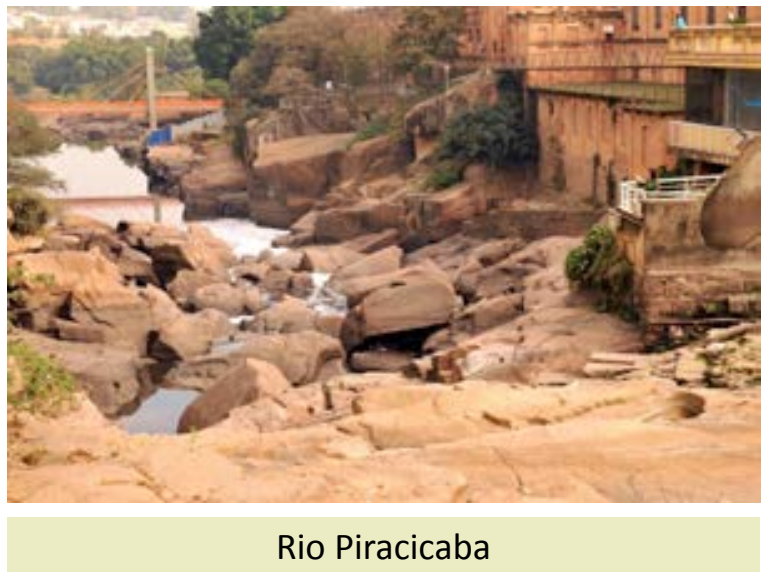




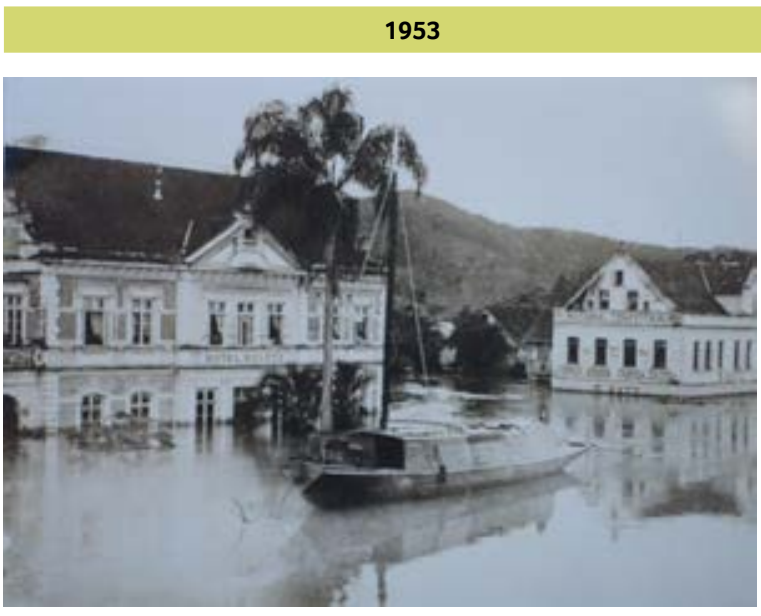

Amazonas
2014

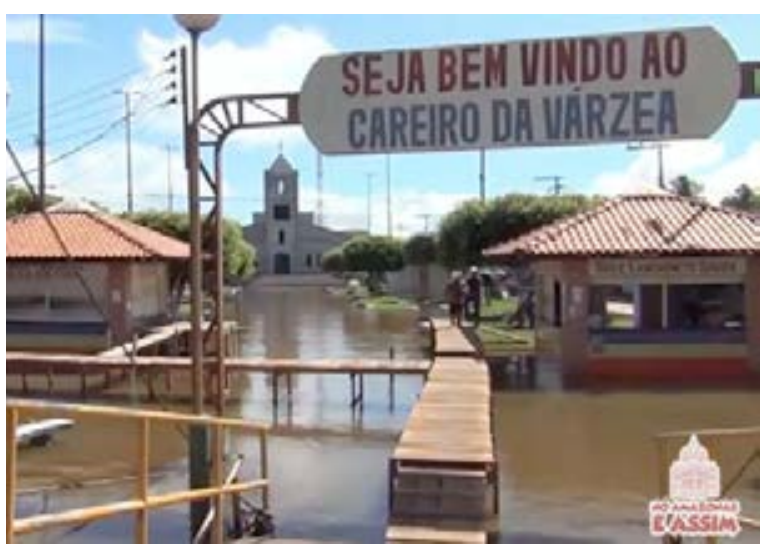

Amazonas

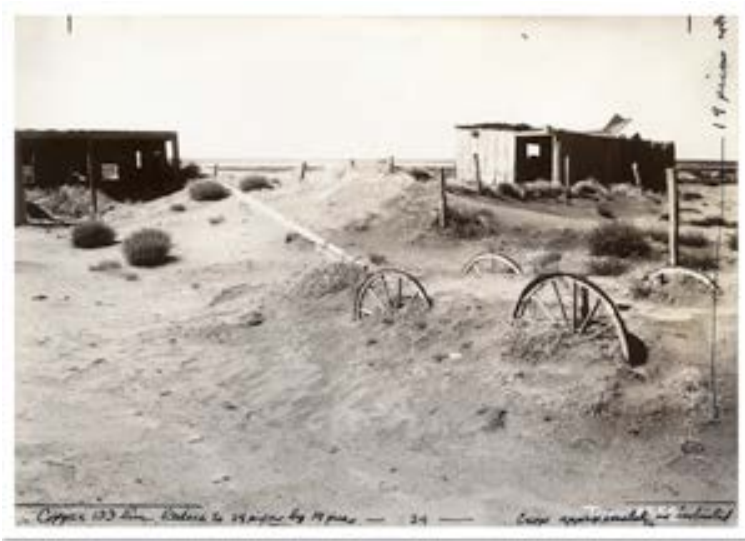

Oeste americano

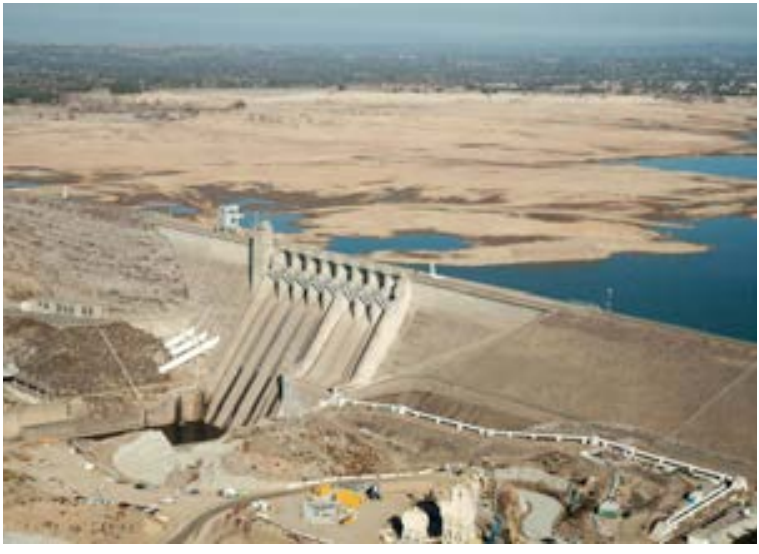

Oeste americano
The Floods of 1953: Graphic - How it all unfolded

g Rowan Mantell

225 PA

G share

\{24 Tweet 3

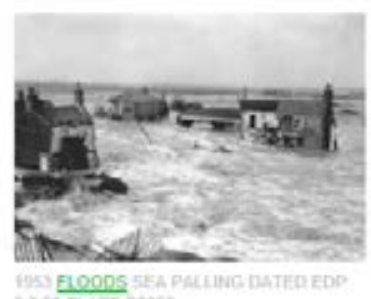

0253 PLATE

The Floods of 1953 brought the sea caging inland, In one evening whole families were wiped out, house destroyed and lives; changed for ever. All this week Rowan Mantell commemorates the heartbreak and the heroes of our worst-ever peacetime disaster.

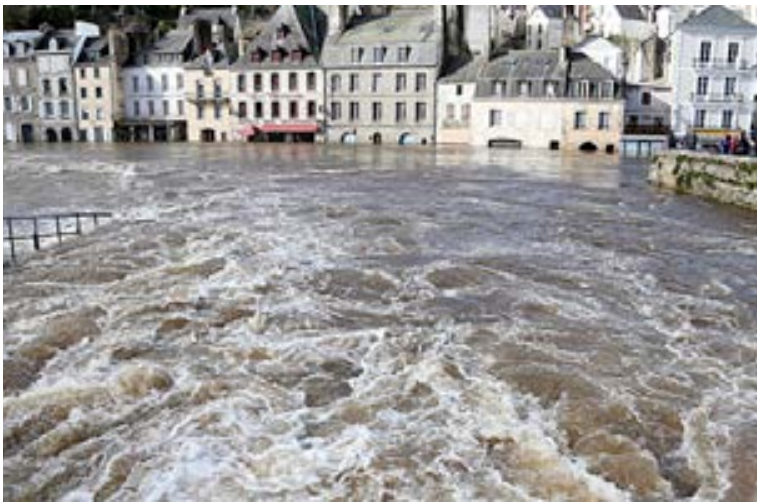

\section{Europa}




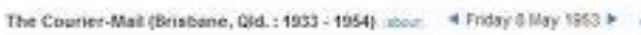

\section{China famine} HONG KONG, May 7 (AAP)-More than a million people were suffering from a widespread famine in Southwest China, a Chinese Communist newspaper reaching here to-day reported.
Worst drought in half a century hits China's bread-basket

\section{तारण}

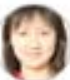

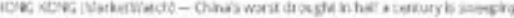

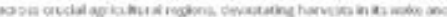
trescaing tont eacoury (M)

\section{China}

The Courier-Mail (Brisbane, Old. : 1933 - 1954) (about) 4 Tuesday 30 June 1953

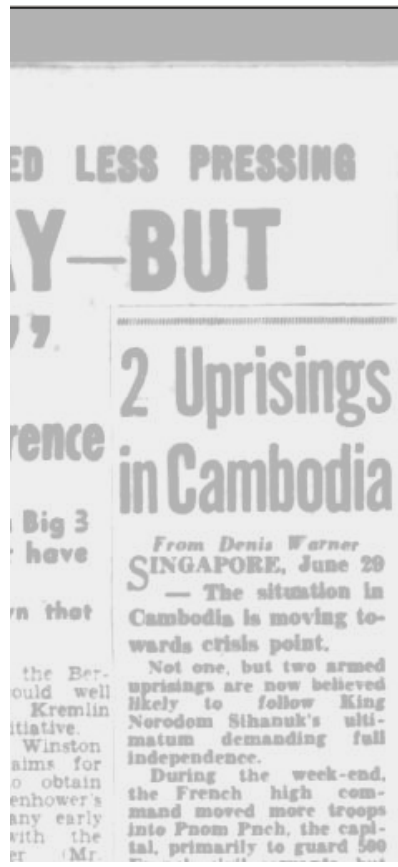

Kyushu Floods

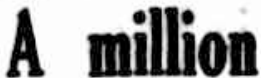
Japanese homeless

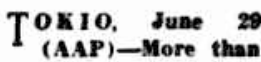
one million Japanese were homeless to-day in the nouthern ialand of Kyouke.

This follows Iisastrous noods which swamped the whole of the isiand and anese houses Police said to-day that the death roll had risen to 423 . missing totalled 310 , and inIt was expected that many more casualties would be re. munications with out
districts were restored.

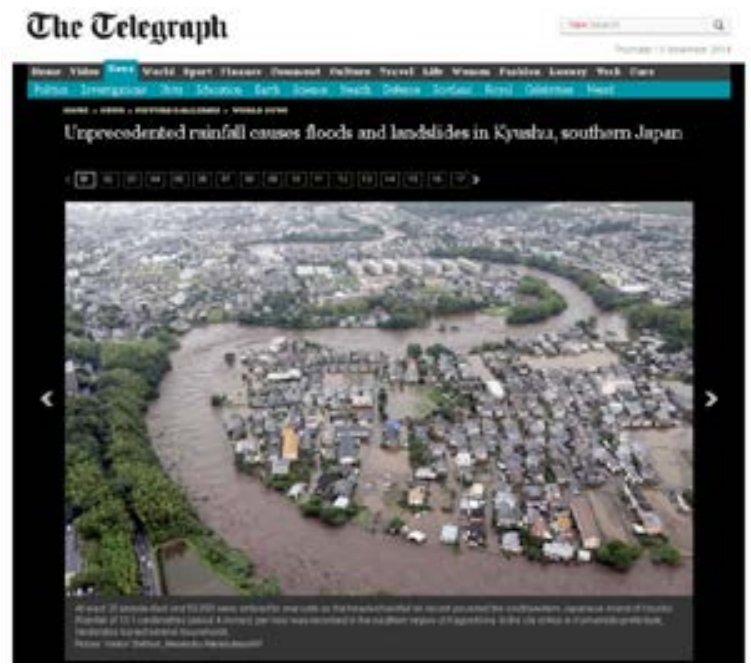

Japão

Figura 19 - Eventos climáticos extremos no Brasil, Estados Unidos, Europa, China e Japão, em 1953 e 2014. 